\title{
A pravasztatin hatása tetrahidrobiopterin-érzékeny és -rezisztens praeeclampsiás placenták NO-szintáz-aktivitására
}

\author{
Pánczél Zita dr. ${ }^{1}$ - Supák Dorina dr. ${ }^{1}$ - Kovács Bence dr. ${ }^{1}$ \\ Kukor Zoltán dr. ${ }^{2}$ - Valent Sándor dr. ${ }^{1}$ \\ 1Semmelweis Egyetem, Általános Orvostudományi Kar, Szülészeti és Nőgyógyászati Klinika, Budapest \\ ${ }^{2}$ Semmelweis Egyetem, Általános Orvostudományi Kar, \\ Orvosi Vegytani, Molekuláris Biológiai és Patobiokémiai Intézet, Budapest
}

\begin{abstract}
Bevezetés: A terhességek 3-8\%-ában megjelenő praeeclampsia kezelése még jelenleg sincs megoldva. Praeeclampsiában elégtelen a NO szintézise, ami hozzájárulhat az emelkedett vérnyomáshoz, proteinuriához, a placenta kóros vascularisatiójához is. Praeeclampsiás placentában a csökkent NO-szintézisnek az is oka lehet, hogy a NO-szintáz affinitása csökken a tetrahidrobiopterinhez (BH4), ezzel BH4-rezisztencia alakul ki. Az utóbbi években állatmodellekben és humánvizsgálatokban is megfigyelték, hogy a pravasztatin védhet a praeeclampsia kialakulása ellen. A pravasztatin egyik ismert pleiotrop hatása az, hogy emeli a NO-szintáz aktivitását.

Célkitüzés: A pravasztatin hatásának leírása a BH4-rezisztens NO-szintáz aktivitására praeeclampsiás placentában.

Módszer: A NO-szintáz aktivitását placentamikroszómában mértük Cl4-arginin szubsztráttal egészséges $(\mathrm{n}=9)$ és praeeclampsiás $(\mathrm{n}=9)$ minta felhasználásával. A NO-szintáz aktivitását $0,02 \mu \mathrm{M}$, fiziológiás $0,2 \mu \mathrm{M}$ és farmakológiás $50 \mu \mathrm{M} \mathrm{BH} 4$ mellett mértük.

Eredmények: 9 praeeclampsiás mintából egy volt BH4-rezisztens; a fiziológiás BH4-koncentráció nem növelte szignifikánsan a NO-szintáz aktivitását, míg az egészséges placenta-mikroszómák aktivitását átlagosan $60 \%$-kal $(\mathrm{p}<0,01)$, a BH4-szenzitív praeeclampsiás minták NO-szintáz-aktivitását $67 \%$-kal $(\mathrm{p}<0,01)$ növelte. $10 \mu \mathrm{M}$ pravasztatin 32-38\%kal növelte a NO-szintáz aktivitását mindegyik BH4-koncentrációnál az egészséges, a BH4-szenzitív és a BH4-rezisztens praeeclampsiás mintákban is.

Következtetés: $10 \mu \mathrm{M}$ pravasztatin a BH4-rezisztens placenta NO-szintáz-aktivitását hasonló mértékben növelte, mint a placenta fiziológás BH4-koncentrációja $(0,06-0,20 \mu \mathrm{M})$ a BH4-érzékeny NO-szintáz aktivitását. Vizsgálatunkkal tehát kimutattuk, hogy a pravasztatin a $\mathrm{BH} 4$-rezisztens praeeclampsiás placenta $\mathrm{NO}$-szintáz-aktivitását fiziológiás szintre emeli.
\end{abstract}

Orv Hetil. 2020; 161(10): 389-395.

Kulcsszavak: praeeclampsia, placenta, NO-szintáz, pravasztatin

\section{Effect of pravastatin on tetrahydrobiopterin-sensitive and -resistant NO synthase activity of preeclamptic placentas}

\footnotetext{
Introduction: The treatment of preeclampsia, which occurs in 3-8\% of pregnancies, is not yet resolved. In preeclampsia, NO synthesis is insufficient, which can contribute to hypertension, proteinuria and abnormal vascularization of the placenta. Decreased NO synthesis in the preeclamptic placenta may also be due to a decrease in the affinity of NO synthase for tetrahydrobiopterin (BH4), resulting in $\mathrm{BH} 4$ resistance. In recent years, pravastatin has been shown to prevent preeclampsia in animal models and in human studies. One of the known pleiotropic effects of pravastatin is that it increases NO synthase activity.

Aim: Description of the effect of pravastatin on BH4-resistant NO synthase activity in the preeclamptic placenta. Method: NO synthase activity in the placental microsome was measured with $\mathrm{Cl} 4$ arginine substrate using healthy $(\mathrm{n}=9)$ and preeclamptic $(\mathrm{n}=9)$ samples. NO synthase activity was measured at $0.02 \mu \mathrm{M}$, physiological at $0.20 \mu \mathrm{M}$ and pharmacological at $50 \mu \mathrm{M} \mathrm{BH} 4$.
} 
Results: One of the 9 preeclamptic patients was BH4-resistant; physiologic BH4 concentration did not significantly increase NO synthase activity, whereas healthy placental microsomes showed a mean increase of $60 \%(\mathrm{p}<0.01)$, and BH4-sensitive preeclamptic specimen showed a $67 \%(\mathrm{p}<0.01)$ increase. $10 \mu \mathrm{M}$ pravastatin increased NO synthase activity by $32-38 \%$ at each $\mathrm{BH} 4$ concentration in healthy, $\mathrm{BH} 4$-sensitive and $\mathrm{BH} 4$-resistant preeclampsia samples. Conclusion: $10 \mu \mathrm{M}$ pravastatin increased $\mathrm{BH} 4$-resistant placental NO synthase activity to a similar extent as placental physiological BH4 concentration $(0.06-0.20 \mu \mathrm{M})$ to BH4-sensitive NO synthase activity. The NO synthase activity of BH4-resistant preeclamptic placenta can be increased by pravastatin to physiological level.

Keywords: preeclampsia, placenta, NO synthase, pravastatin

Pánczél Z, Supák D, Kovács B, Kukor Z, Valent S. [Effect of pravastatin on tetrahydrobiopterin-sensitive and -resistant NO synthase activity of preeclamptic placentas]. Orv Hetil. 2020; 161(10): 389-395.

(Beérkezett: 2019. október 21.; elfogadva: 2019. november 20.)

\begin{abstract}
Rövidítések
$\mathrm{BH} 2$ = dihidrobiopterin; $\mathrm{BH} 4=$ tetrahidrobiopterin; $\mathrm{eNOS}=$ endothelialis NOS; ETT = Egészségügyi Tudományos Tanács; ISSHP $=$ International Society for the Study of Hypertension in Pregnancy; IUGR = (intrauterine growth retardation) méhen belüli növekedési elmaradás; NADPH = (nicotinamide adenine dinucleotide phosphate) nikotinamid-adenin-dinukleotid-foszfát; $\mathrm{NO}=$ nitrogén-monoxid; NOS = nitrogén-monoxid-szintáz; pra = pravasztatin; sVEGFR $=($ soluble vascular endothelial growth factor receptor) az oldható vascularis endothelialis növekedési faktor receptora; TUKEB = Tudományos és Kutatásetikai Bizottság
\end{abstract}

A praeeclampsia jelenleg is a legveszélyesebb terhességi kórképek közé tartozik, oki kezelése és hatékony megelőzése kielégítően a mai napig sincs megoldva. Kialakulásában a placentának kulcsszerepe van, ezért súlyosabb esetben a terhességet meg kell szakítani, a placenta eltávolításával a tünetek gyorsan enyhülnek. A hatékony kezelést az is akadályozza, hogy a betegség multifaktoriális: elégtelen táplálkozás, környezeti, genetikai tényezők egyaránt befolyásolják a kialakulását [1].

A NO mint hatékony fiziológiás vérnyomáscsökkentő szer már több mint húsz éve ismert [2]. A NO-t NOszintáz izoenzimek szintetizálják argininból. A praeeclampsia egyik kritériuma a terhesség alatt kialakuló hypertonia [3]. Emiatt régen felmerült és igazolódott, hogy az elégtelen NO-termelés hozzájárulhat a praeeclampsia kialakulásához. A csökkent, hatékony NO-szint kialakulásának több oka lehet. Hozzájárul a praeeclampsiás nők oxidatív stressze. A NO és a szuperoxid azonnal reaktív peroxinitritté alakul:

$$
\mathrm{NO}+\mathrm{O}_{2}^{-} \rightarrow \mathrm{ONO}_{2}^{-}
$$

A NO átalakulása mellett a peroxinitrit is a patológiás folyamatokat erősíti. Oxidálóhatásán túl fehérjéket nitrálhat, múködésüket rontva [4]. A placentában elsősorban az endothelialis NO-szintáz (eNOS) izoforma található. A NOS múködése tetrahidrobiopterint (BH4) igényel. Korábbi munkánk során kimutattuk, hogy a placenta BH4-koncentrációja a féltelítési tartományban $(0,11 \mu \mathrm{M})$ található, így a BH4 szintje jelentősen módo- síthatja az enzimaktivitást. Az elsô trimeszterben a trophoblast átlagos $\mathrm{BH} 4$-koncentrációja körülbelül 0,20 $\pm 0,09 \mu \mathrm{M}$, a terhesség terminusa után átlagosan 0,057 $\pm 0,023 \mu \mathrm{M}[5,6]$. A terhesség végén csökkenő NOSaktivitás tapasztalható, ehhez hozzájárulhat a BH4-szint csökkenése is. Praeeclampsiás placenták eNOS-aktivitását mérve azt tapasztaltuk néhány esetben, hogy az nem emelkedik fiziológiás BH4-szintnél, a maximális aktivitás eléréséhez nagyon magas BH4-koncentráció szükséges. Ezeket a mintákat BH4-rezisztenseknek neveztük [5].

A sztatinok (3-hidroxi-3-metil-glutaril-koenzim-A-reduktáz-inhibitorok) a leggyakrabban használt koleszterinszint-csökkentő gyógyszerek. Elsődleges hatásukon kívül a sztatinok pleitrop hatásokkal is rendelkeznek. Pleiotrop hatásaik közé proangiogén, antiinflammatoricus, antioxidáns, neuroprotektív és antitrombotikus tulajdonságok is tartoznak, beleértve az endothelium védelmét is. A praeeclampsia endothelkárosodást is okoz, így a sztatinok potenciális terápiás használata praeeclampsiás betegeknél régen felmerült. A sztatinok potenciális teratogén hatásuk miatt terhesség alatt nem alkalmazhatók. Néhány bevezető tanulmány arra utal, hogy használatuk nagy kockázatú csoportban előnyös lehet. Egy pilotmunkában 20 magas kockázatú beteget véletlenszerüen két csoportra osztottak, az egyik csoportot pravasztatinnal, a másikat placebóval kezelték. A placebocsoport $40 \%$-ánál praeeclampsia alakult ki, míg a pravasztatinos csoportban nem volt praeeclampsiás eset [7].

\section{Módszer}

A vizsgálatba egészséges és praeeclampsiás terhes nőket vontunk be. A vizsgálathoz az etikai engedélyt az ETT TUKEB adta meg (az engedély száma: 48995-2016/ EKU). A betegek a praeeclampsia diagnosztikai kritériumát az International Society for the Study of Hypertension in Pregnancy (ISSHP) 2018-as közleménye [3] szerint minden esetben kimerítették, a praeeclampsiás nőknek a terhesség 20. hetét követően a vérnyomása 140/90 Hgmm-nél nagyobb volt, és a vizelettel ürített fehérje meghaladta a $300 \mathrm{mg} /$ nap értéket, vagy a vizelet 
fehérjetartalma legalább ++ volt. Közvetlenül szülés után jég között a placentát átszállítottuk a laboratóriumba. A humán placentamikroszóma frakciójának van a legmagasabb NOS-aktivitása [8], emiatt késlekedés nélkül mikroszómát preparáltunk belőle a már közölt módon [9]. A mikroszóma-frakcióból fehérjemeghatározásra mintákat különítettünk el, majd legalább három részre osztva a mintákat $-80{ }^{\circ} \mathrm{C}$-on tároltuk felhasználásig. A NOszintáz aktivitását maximális enzimaktivitást biztosító körülmények között (40 mM Na/HEPES pH = 7,4; $1 \mathrm{mM} \mathrm{Ca}^{2+} ; 1 \mathrm{mM} \mathrm{Mg}{ }^{2+} ; 1 \mathrm{mM}$ ditiotreitol) határoztuk meg különböző BH4-koncentrációknál. A NOS aktivitását placenta-mikroszómában mértük Cl4-arginin szubsztráttal egészséges $(\mathrm{n}=9)$ és praeeclampsiás $(\mathrm{n}=9)$ minta felhasználásával. A mikroszóma preparálásakor a vízoldékony, kis molekulatömegû anyagok nagy része a citoszól frakcióban marad, így a BH4 is. A BH4 érzékeny oxidációra, dihidrobiopterinné (BH2) alakul [10, 11]. A BH2 már nem kötődik az enzimhez, aktivitását nem emeli. Az oxidáció sebessége $\mathrm{pH}$ - és hőmérsékletfüggő, a tároláshoz használt enyhén savas $(\mathrm{pH}=5,0)$ közegben, $-80{ }^{\circ} \mathrm{C}$-on az oxidáció lassú, fiziológiás környezetben $\left(\mathrm{pH}=7,4 ; 37^{\circ} \mathrm{C}\right)$ felgyorsul. Az aktivitás meghatározását az oxidáció okozta artefaktum elkerülése végett mindig BH4-érzékeny, egészséges szülésből származó standard mikroszómaminta használata mellett végeztük. Az enzimaktivitást az alapaktivitást biztosító $0,02 \mu \mathrm{M}$, fiziológiás $0,2 \mu \mathrm{M}$ és farmakológiás $50 \mu \mathrm{M}$ BH4 mellett mértük. A BH4-et közvetlenül a reakció elindítása előtt mértük a reakcióelegybe. A pravasztatin hatását $10 \mu \mathrm{M}$ koncentrációnál vizsgáltuk.

\section{Eredmények}

Munkánk során 9 egészséges és 9 praeeclampsiás terhességből származó placenta eNOS-aktivitását vizsgáltuk. A vizsgálatba bevont páciensek klinikai adatait az 1. táb-

1. táblázat $\mid$ A vizsgálatban részt vevők klinikai adatai (Az értékek átlagot \pm SD jelentenek)

\begin{tabular}{llll}
\hline & $\begin{array}{l}\text { Kontroll } \\
\mathrm{n}=9\end{array}$ & $\begin{array}{l}\text { Praeeclampsiás } \\
\mathrm{n}=9\end{array}$ & \\
\hline Anyai életkor (év) & $30,4 \pm 3,9$ & $31,8 \pm 8,2$ & $\mathrm{n} . \mathrm{s}$. \\
\hline $\begin{array}{l}\text { Szisztolés vérnyomás } \\
\text { (Hgmm) }\end{array}$ & $108,9 \pm 7,8$ & $163,3 \pm 17,3$ & $\mathrm{p}<0,001$ \\
\hline $\begin{array}{l}\text { Diasztolés vérnyomás } \\
\text { (Hgmm) }\end{array}$ & $74,3 \pm 6,7$ & $103,3 \pm 7,1$ & $\mathrm{p}<0,001$ \\
\hline $\begin{array}{l}\text { Vizeletfehérje } \\
\text { Terminus (hét) }\end{array}$ & 0 & ++ vagy & \\
\hline $\begin{array}{l}\text { Terhesség alatti } \\
\text { súlygyarapodás (kg) }\end{array}$ & $12,0 \pm 2,4$ & $9,8 \pm 7,9$ & $\mathrm{n} . \mathrm{s}$. \\
\hline $\begin{array}{l}\text { Az újszülött tömege } \\
\text { (gramm) }\end{array}$ & $3449 \pm 132$ & $1983 \pm 641$ & $\mathrm{p}<0,001$ \\
\hline
\end{tabular}

n. s. = nem szignifikáns

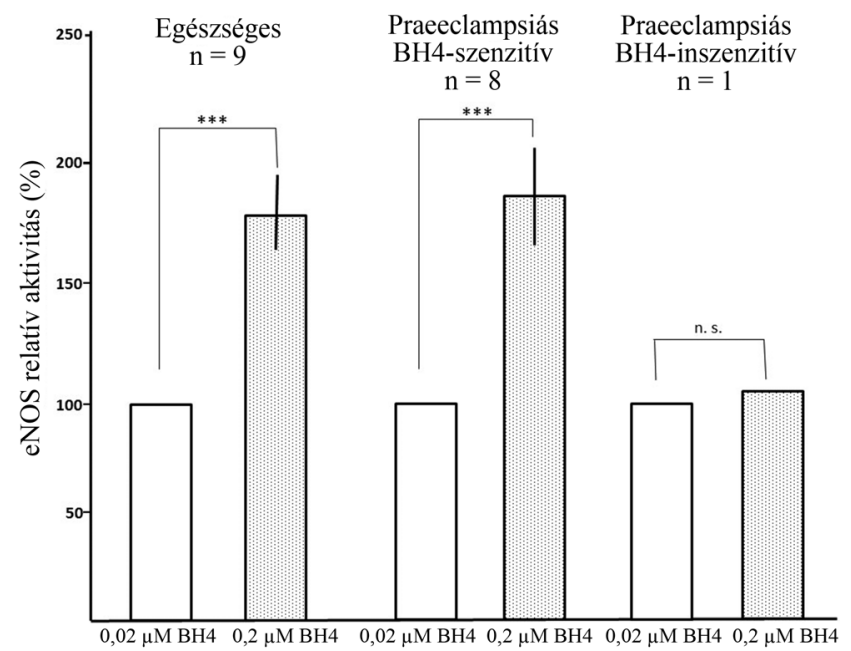

1. ábra Placenta-mikroszómák relatív NOS-aktivitása fiziológiás $\mathrm{BH} 4-$
koncentráció mellett. A $100 \%$-os $($ alap)aktivitás $0,02 \mu \mathrm{M} \mathrm{BH} 4$
mellett mért enzimaktivitás $(0,02 \mu \mathrm{M} \mathrm{BH} 4)$. A fiziológiás, 0,2
$\mu \mathrm{M}$ BH4 mellett mért aktivitások $(0,2 \mu \mathrm{M} \mathrm{BH} 4)$ az egészséges
és a BH4-szenzitív mintáknál átlag \pm SD értéket jelentenek
${ }^{* *} \mathrm{p}<0,001$
$\mathrm{BH} 4=$ tetrahidrobiopterin; NOS $=\mathrm{NO}$-szintáz; n. s. $=$ nem
szignifikáns; $\mathrm{SD}=$ standard deviáció

lázat tartalmazza. A 9 praeeclampsiás minta NOS-aktivitásából egy volt $\mathrm{BH} 4$-rezisztens. A BH4-rezisztens páciens klinikai képe nem tért el a vizsgált praeeclampsiás esetekétől. Legmagasabb mért vérnyomása 160/110 Hgmm volt (a többi praeeclampsiásé 150-200/90-110 Hgmm); vizelet-fehérjetartalma ++; terhessége 31 hétig tartott (a többi praeeclampsiásé 30-37 hétig), az újszülött intrauterin növekedési retardált (IUGR) volt, súlya $1450 \mathrm{~g}$ (a többi patológiás esetben egy IUGR-eset volt, az újszülöttek tömege 1210-3360 g); a terhesség alatti súlygyarapodása $8 \mathrm{~kg}$ (a többi praeeclampsiásé - (!) 8-18 $\mathrm{kg}$ ). Ennek a mintának fiziológiás, 0,20 $\mathrm{MM}$ BH4-koncentrációja nem növelte szignifikánsan a NOS aktivitását, míg az egészséges placenta-mikroszómák aktivitását átlagosan 60\%-kal ( $\mathrm{p}<0,01)$, a BH4-szenzitív praeeclampsiás minták NOS-aktivitását $67 \%$-kal $(\mathrm{p}<0,01)$ növelte a 0,02 $\mu \mathrm{M} \mathrm{BH} 4$ mellett mért alapaktivitáshoz képest (1. ábra). $50 \mu \mathrm{M}$ BH4 mindhárom csoport (egészséges, BH4szenzitív és BH4-inszenzitív praeeclampsiás) NOS-aktivitását több mint a kétszeresére növelte (2. ábra). $10 \mu \mathrm{M}$ pravasztatin 32-38\%-kal növelte a NOS aktivitását mind az egészséges, mind a BH4-szenzitív és BH4-inszenzitív mintákban. A hatás hasonló volt mindhárom BH4-koncentráció mellett; a 3. ábra a fiziológiás, $0,20 \mu \mathrm{M} \mathrm{BH4-}$ koncentrációnál mért pravasztatinhatást mutatja.

\section{Megbeszélés}

A humán placenta $\mathrm{BH} 4$-koncentrációja az eNOS $\mathrm{K}_{\mathrm{M}}$-értékének $(0,11 \mu \mathrm{M})$ tartományában található. Az első trimeszterben a placenta átlagos $\mathrm{BH} 4$-koncentrációja en- 


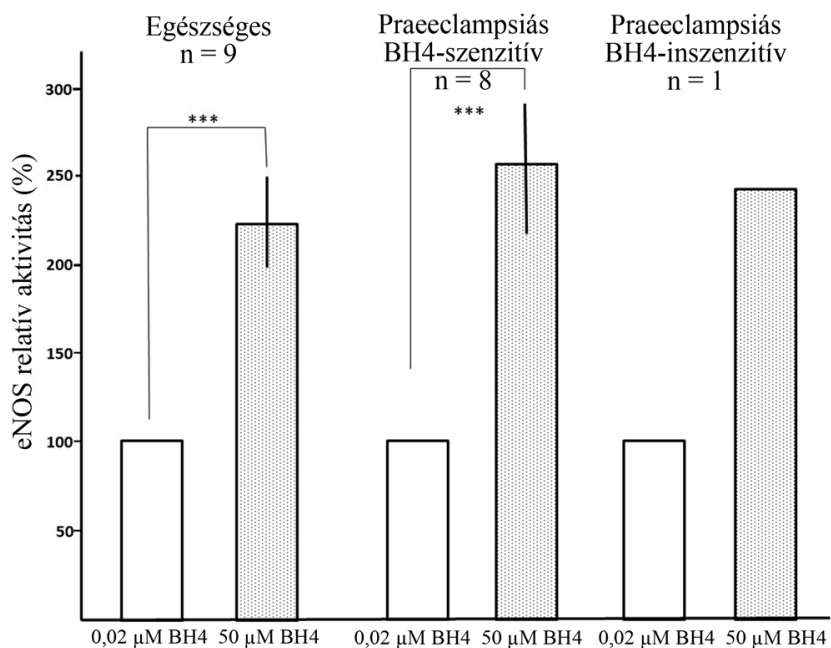

2. ábra $\mid$ Placenta-mikroszómák relatív NOS-aktivitása 50 uM BH4-kon centráció mellett. A $100 \%$-os (alap)aktivitás $0,020 \mu \mathrm{M} \mathrm{BH} 4$ mellett mért enzimaktivitás $(0,02 \mu \mathrm{M}$ BH4). Az $50 \mu \mathrm{M}$ BH4 mellett mért aktivitások ( $50 \mu \mathrm{M}$ BH4) az egészséges és a $\mathrm{BH} 4$ szenzitív mintáknál átlag \pm SD értéket jelentenek

${ }^{* * *} \mathrm{p}<0,001$

$\mathrm{BH} 4=$ tetrahidrobiopterin $; \mathrm{NOS}=\mathrm{NO}$-szintáz $; \mathrm{SD}=$ standard deviáció

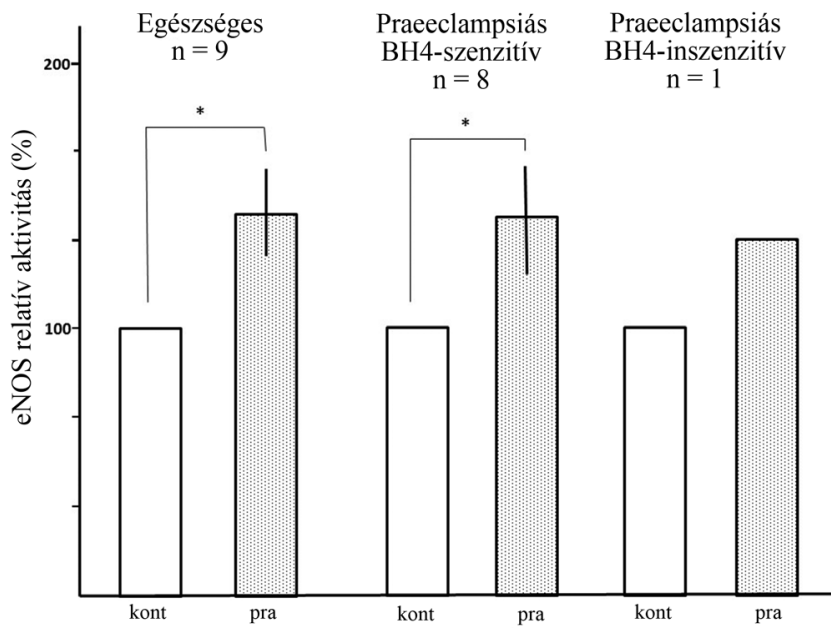

3. ábra

A pravasztatin hatása placenta-mikroszóma relatív NOS-aktivi-
tására. A NOS-aktivitás minden pontban fiziológiás, $0,2 \mu \mathrm{M}$
BH4 mellett mérve. A 100\%-os (kont) aktivitás pravasztatin nél-
kül, $0,2 \mu \mathrm{M}$ BH4 jelenlétében mért enzimaktivitás. A $10 \mu \mathrm{M}$
pravasztatin (pra) mellett mért aktivitások az egészséges és a
BH4-szenzitív mintáknál átlag \pm SD értéket jelentenek
*p<0,05
BH4 = tetrahidrobiopterin; NOS = NO-szintáz; SD = standard
deviáció

nek kb. duplája $(0,20 \mu \mathrm{M})$, ami a terhesség végére a harmadára $(0,06 \mu \mathrm{M})$ csökken. A NOS aktivitása a placentában tehát jelentősen függ a $\mathrm{BH} 4$-koncentrációtól. $\mathrm{Az}$ eNOS dimer szerkezetű, két BH4-et köthet antikooperatív módon. Az első BH4 kötése nagy affinitással történik, fiziológiás BH4-koncentrációk telítik, ez eredmé- nyezi az eNOS alapaktivitását. A második BH4-et kis affinitással $\left(\mathrm{K}_{\mathrm{M}}=0,11 \mu \mathrm{M}\right)$ köti az eNOS, így a terhesség végére a placenta NOS-aktivitása a maximális enzimaktivitáshoz képest csökken. Korábbi munkánk szerint 10 praeeclampsiás placentahomogenizátumból 7 BH4-inszenzitívnek bizonyult [6]. Későbbi tanulmányok során kiderült, hogy a BH4 igen érzékeny a spontán oxidációra. Emiatt a placenta-eNOS BH4-szenzivitását kimutató metodikán változtattunk. A placentahomogenizátumot mikroszómára cseréltük, ezzel a homogenizátumban lévő reaktívoxigén-származékokat eltávolítottuk. A módosított módszerrel mérve a $\mathrm{BH} 4$-inszenzitív placenták aránya jelentősen csökkent, 9 mintából egy mutatott inszenzitivitást. Ez arra utal, hogy praeeclampsiában előfordulhat $\mathrm{BH} 4$-inszenzivitás, de a praeeclampsiás eseteknek kis részét érintheti. Az általunk vizsgált kis esetszám miatt nem határozható meg, hogy a praeeclampsiában szenvedők hány százalékát érintheti a NOS BH4-érzéketlensége.

A BH4-inszenzitivitás többféleképpen is magyarázható. Egyrészt a praeeclampsiára jellemző oxidatív stressz eliminálhatja a $\mathrm{BH} 4$-et, csökkentheti a NO-termelést [12], látszólagos inszenzitivitást okozva. Ezt alátámasztja, hogy placentahomogenizátumot vizsgálva az oxidatív stressz alatt álló praeeclampsiás minták jelentős része BH4-inszenzitívnek bizonyult, míg az egészséges minták BH4-szenzitívek voltak, ezzel ellentétben mikroszómát használva a praeeclampsiás 9 minta közül egy mutatott inszenzitivitást. A humán placenta-mikroszóma NADPH jelenlétében termelhet reaktívoxigén-gyököket [13]. A NOS múködése NADPH-igényes, ezért elképzelhető, hogy a megfigyelt esetünkben a $\mathrm{BH} 4$-inszenzitivitást a túltermelt oxidatív gyökök okozták. Az oxidatív stressz okozta BH4-szint-csökkenés ellen antioxidáns kezelés segíthetne a betegeken. Korábbi munkánk során kimutattuk, hogy az aszkorbinsav védi a BH4-et az oxidációtól [10]. Több munkacsoport is vizsgálta az antioxidánsok (többek között C- és E-vitamin) preventív szerepét praeeclampsia ellen, de egy friss metaanalízis nem támasztotta alá a felvetést [14]. A BH4-inszenzitivitás másik oka lehet a NOS BH4-affinitásának csökkenése, akár fehérjeszerkezetet érintő mutáció, akár poszttranszlációs módosítás, akár környezeti tényező miatt. Környezeti tényező lehet a terhesség alatti cinkellátottság. Az eNOS BH4-kötő doménje közel található a $\mathrm{Zn}^{2+}$-kötő doménjéhez, és a $\mathrm{Zn}^{2+}$ segíti az enzim $\mathrm{BH} 4$ kötését. A cinkhiány így csökkentheti az enzim affinitását a BH4-hez [15]. Ezt alátámasztja, hogy csökkent $\mathrm{Zn}^{2+}$ tartalmat figyelt meg egy török munkacsoport praeeclampsiás nők placentájában [16]. A kivitelezhetőbb szérumcinkkoncentráció-mérések eredményei ellentmondásosak. Pár éve elvégzett metaanalízisek szerint praeeclampsiás terhes nők szérumcinkszintje alacsonyabb, mint az egészséges terhes nóké $[17,18]$. A cink antioxidáns hatású, több mint 100 enzim múködéséhez szükséges [19], emiatt nehéz kielégítő pontossággal magyarázni a cinkkezelések hatásmechanizmusát és azt, hogy a cink- 
pótlás előnyös hatásaihoz milyen mértékben járulhat hozzá a NOS. Az értelmezést az is nehezíti, hogy a cinket étrend-kiegészítőként nem önállóan, hanem egyéb ásványi anyagokkal, vitaminokkal együtt alkalmazzák. A cink mellett adott anyagok szintén befolyásolhatják a terhesség kimenetelét, ráadásul az orálisan alkalmazott cink felszívódását, hasznosulását is módosítják [20-22].

A praeeclampsia multifaktoriális betegség, oka és oki kezelése nem ismert, súlyosabb esetben a terhesség terminációjával kezelik. A sztatinok lehetséges kedvező hatását praeeclampsiában állatkísérletekben és humánvizsgálatokban is nyomon követték. Patkányokban sVEGFR-overexpresszióval és CBA/J x DBA/2 egerekben kiváltott kísérletes praeeclampsiát sikeresen kezeltek pravasztatinnal [23]. Praeeclampsiára nagy kockázatú (magas testtömegindex, dislipidaemia, hypertonia stb.) terhes nőket pravasztatinnal kezelve csökkent a praeeclampsiás esetek aránya a kontrollcsoporthoz képest [7]. A sztatinok hatásmechanizmusa praeeclampsiás esetekben jelenleg intenzíven kutatott terület. Régóta ismert, hogy praeeclampsiában elégtelen a NO-termelés, ami a vérnyomás emelkedésén túl a placenta elégtelen vascularisatiójához, tápanyagellátásához is hozzájárulhat. Humánvizsgálatokban igazolták, hogy a pravasztatin növelheti a vena umbilicalis endothelsejtekben a NOS-expressziót, tehát az enzimaktivitás emelkedése viszonylag lassan, órák, napok alatt zajlódik le [24]. Korábbi munkánkban kimutattuk, hogy a pravasztatin gyorsan is képes expressziótól és foszforilációtól függetlenül a humán placenta NOS-aktivitását növelni. A hatás azon alapszik, hogy a pravasztatin növeli a NOS szubsztrátjának, az argininnak a felvételi sebességét, így az enzim argininellátottsága javul [9]. Praeeclampsiás terhességben megfigyelték, hogy csökkenhet a szérum argininszintje, ami hozzájárulhat a NOS-aktivitás csökkenéséhez, és emelheti az oxidatív stresszt [25]. A pravasztatin argininfelvételt növelő hatása így csökkentheti a placenta argininhiányát. Humán vena umbilicalis endothelsejteket argininnal kezelve sikerült az oxidatív stresszt is mérsékelni [16]. Praeeclampsiában fokozott oxidatív stressz figyelhető meg. Az oxidatív stressz endothelkárosodást, gyulladásos reakciót, vérnyomás-emelkedést okozhat. A placenta oxidatív stresszét növelheti a szuperoxid a BH4 oxidációjával. Az oxidálódott $\mathrm{BH} 4$ az eNOS szétkapcsolását eredményezheti, aminek során elektron kerülhet a molekuláris oxigénre, de az arginin már nem oxidálódik, a reakció végén szuperoxid képződik [26]. Az élettani terhességekben a placenta trophoblastsejtjei mélyen behatolnak a méh állományába, és az arteria spiralisokat átalakítják (remodelling). A remodellinget is károsíthatja az oxidatív stressz. Az ok-okozati viszonyok helyes értelmezése jelenleg részleteiben nem tisztázott. Fiziológiás terhességekben a cytotrophoblast hypoxiás környezetben van, a hypoxia oxidatív stresszhez vezet, így a fokozott oxidatív stressz normálisnak tekinthető. Az abnormális remodelling elégtelen oxigénellátottságot okoz, így a trophoblastinvázió akadályoztatottsága is vezethet oxidatív stresszhez. Az úgynevezett „kétlépcsős modell” szerint az abnormális implantáció, csökkent lepényi perfúzió következtében (első lépcső) a keringésbe olyan faktorok kerülnek (sVEGFR, szolúbilis endoglin), amelyek az anyai tünetek megjelenéséért (második lépcső) felelősek $[27,28]$.

Vizsgált esetünkben a BH4-inszenzitív placentának NOS-alapaktivitása van, amely nem emelhető fiziológiás koncentrációjú $\mathrm{BH} 4$-gyel. A pravasztatin viszonylag enyhe (34\%-os) NOS-aktivitást növelő hatása viszont elegendő ahhoz, hogy az enzim aktivitását fiziológiás tartományba emelje (4. ábra). A placenta fiziológiás BH4-koncentrációja $K_{M}$ körüli érték, a NOS nem éri el maximális aktivitását. A pravasztatin enyhe NOS-aktivitás-növelő hatása előnyös lehet, mert az aktivitás ilyen mértékű emelésével a fiziológiás tartományba kerül a NOS-aktivitás. Az emelkedett NO-termelés csökkentheti a vérnyomást, enyhítheti a praeeclampsiában is megfigyelt vascularis resisztenciát [29, 30]. Megfigyelésünk egy esetre korlátozódik, így további vizsgálatokra lesz szükség ahhoz, hogy az esetleges terápiás hasznot megállapíthassuk. A minimális esetszám ellenére biztató, hogy kimutattuk: pravasztatinnal a placenta NOS-aktivitása fiziológiás szintre emelhető.

A sztatinterápia jelenleg kontraindikált terhesség alatt. A vizsgálatok eddigi eredményei ellentmondásosak. Néhány, kis esetszámú humánvizsgálat történt eddig. Van, amelyik nem támasztotta alá a pravasztatin feltételezett toxicitását, de volt olyan vizsgálat is, amelyben súlyos születési rendellenesség fordult elő a pravasztatinnal kezelt csoportban. Korai, önkéntes bejelentéseken alapuló beszámolóban idegrendszeri károsodást, végtag-rendellenességet írtak le. A vizsgált esetszám növelésével a súlyos rendellenességek előfordulásának aránya közeledett

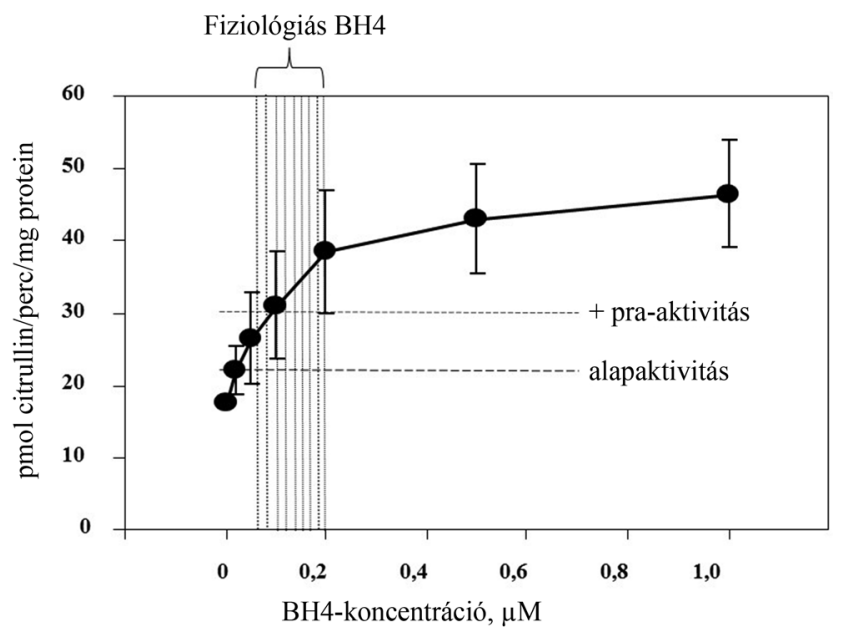

4. ábra Egészséges placenta-mikroszóma NOS-aktivitásának BH4-kon-
centráció-függése. A vonalkázással jelölt rész az egészséges pri-
mordialis és érett placenták átlagos BH4-koncentrációját jelzi
$\mathrm{n}=9 \pm \mathrm{SD}$
BH4 = tetrahidrobiopterin; NOS = NO-szintáz; pra = pravasz-
tatin; SD = standard deviáció tatin; $\mathrm{SD}=$ standard deviáció 
a sztatinnal kezelt és kezeletlen csoportok között. Nagyobb számú esetet vizsgálva enyhe következménynek számító korai terminust $(38,4$ vs. 39,3 hét; $\mathrm{p}<0,04)$ és kisebb születési súlyt $(3,14$ vs. $3,45 \mathrm{~kg} ; \mathrm{p}=0,01)$ figyeltek meg. A súlyos események - mint halvaszületés (1-1 eset kezelt és kezeletlen csoportban), spontán abortusz (14 vs. 11) - kis száma miatt statisztikai adatokkal alátámasztott következtetéseket még nem lehet levonni [31, 32]. A terhesség alatt történő pravasztatinkezelés kockázatainak megállapításához nagy esetszámú felmérésre lenne szükség. Az eddigi eredmények szerint a pravasztatin védhet praeeclampsiával szemben, mérséklődhet az intrauterin növekedési retardáció mértéke is $[33,34$, $35]$.

Anyagi támogatás: A kézirat elkészülését és a kutatómunkát a Semmelweis Egyetem kutatási alapja és a Magyar Hypertonia Társaság anyagi támogatása tette lehetővé.

Szerzői munkamegosztás: K. Z., V. S., P. Z.: Tervezés. K. Z., V. S., S. D., P. Z., K. B.: Mintagyüjtés. K. Z., S. D., K. B.: Klinikai adatok. K. Z., S. D., K. B.: Biokémiai mérés, adatfeldolgozás. K. Z., P. Z., V. S., S. D., K. B.: A kézirat összeállítása, megírása. A cikk végleges változatát valamennyi szerző elolvasta és jóváhagyta.

Érdekeltségek: A szerzőknek nincsenek anyagi érdekeltségeik.

\section{Irodalom}

[1] Peraçoli JC, Borges VT, Ramos JG, et al. Pre-eclampsia/eclampsia. Rev Bras Ginecol Obstet. 2019; 41: 318-332.

[2] Moncada S. Nitric oxide. J Hypertens Suppl. 1994; 12: S35S39.

[3] Brown MA, Magee LA, Kenny LC, et al. The hypertensive disorders of pregnancy: ISSHP classification, diagnosis \& management recommendations for international practice. Pregnancy Hypertens. 2018; 13: 291-310.

[4] Kukor Z, Valent S. Nitric oxide and preeclampsia. [A nitrogénmonoxid-szintézis zavarai praeeclampsiában.] Orv Hetil. 2010; 151: 2125-2135. [Hungarian]

[5] Kukor Z, Mészáros G, Hertelendy F, et al. Calcium-dependent nitric oxide synthesis is potently stimulated by tetrahydrobiopterin in human primordial placenta. Placenta 1996; 17: 69-73.

[6] Kukor Z, Valent S, Tóth M. Regulation of nitric oxide synthase activity by tetrahydrobiopterin in human placentae from normal and pre-eclamptic pregnancies. Placenta 2000; 21: 763-772.

[7] Costantine MM, Cleary K, Hebert MF, et al. Safety and pharmacokinetics of pravastatin used for the prevention of preeclampsia in high-risk pregnant women: a pilot randomized controlled trial. Am J Obstet Gynecol. 2016; 214: 720.el-720.el7.

[8] Sahin-Tóth M, Kukor Z, Tóth M. Tetrahydrobiopterin preferentially stimulates activity and promotes subunit aggregation of membrane-bound calcium-dependent nitric oxide synthase in human placenta. Mol Hum Reprod. 1997; 3: 293-298.

[9] Pánczél Z, Kukor Z, Supák D, et al. Pravastatin induces NO synthesis by enhancing microsomal arginine uptake in healthy and preeclamptic placentas. BMC Pregnancy Childbirth 2019; 19: 426 .
[10] Tóth M, Kukor Z, Vallent S. Chemical stabilization of tetrahyd robiopterin by L-ascorbic acid: contribution to placental endothelial nitric oxide synthase activity. Mol Hum Reprod. 2002; 8: 271-280.

[11] Valent S, Tóth M. Spectrophotometric analysis of the protective effect of ascorbate against spontaneous oxidation of tetrahydrobiopterin in aqueous solution: kinetic characteristics and potentiation by catalase of ascorbate action. Int J Biochem Cell Biol. 2004; 36: 1266-1280.

[12] Hesthammer R, Eide T, Thorsen E, et al. Decrease of tetrahydrobiopterin and NO generation in endothelial cells exposed to simulated diving. Undersea Hyperb Med. 2019; 46: 159-169.

[13] Milczarek R, Sokolowska E, Hallmann A, et al. The NADPHand iron-dependent lipid peroxidation in human placental microsomes. Mol Cell Biochem. 2007; 295: 105-111.

[14] Conde-Agudelo A, Romero R, Kusanovic JP, et al. Supplementation with vitamins $\mathrm{C}$ and $\mathrm{E}$ during pregnancy for the prevention of preeclampsia and other adverse maternal and perinatal outcomes: a systematic review and metaanalysis. Am J Obstet Gynecol. 2011; 204: 503.el-503.el2.

[15] Chreifi G, Li H, McInnes CR, et al. Communication between the zinc and tetrahydrobiopterin binding sites in nitric oxide synthase. Biochemistry 2014; 53: 4216-4223.

[16] Açikgoz S, Harma M, Harma M, et al. Comparison of angiotensin-converting enzyme, malonaldehyde, zinc, and copper levels in preeclampsia. Biol Trace Elem Res. 2006; 113: 1-8.

[17] Ma Y, Shen X, Zhang D. The relationship between serum zinc level and preeclampsia: a meta-analysis. Nutrients 2015; 7: 7806-7820.

[18] Zhu Q, Zhang L, Chen X, et al. Association between zinc level and the risk of preeclampsia: a meta-analysis. Arch Gynecol Obstet. 2016; 293: 377-382.

[19] Hovdenak N, Haram K. Influence of mineral and vitamin supplements on pregnancy outcome. Eur J Obstet Gynecol Reprod Biol. 2012; 164: 127-132.

[20] Azami M, Azadi T, Farhang S, et al. The effects of multi mineralvitamin $\mathrm{D}$ and vitamins $(\mathrm{C}+\mathrm{E})$ supplementation in the prevention of preeclampsia: an RCT. Int J Reprod Biomed (Yazd). 2017; 15: 273-278.

[21] Zahiri Sorouri Z, Sadeghi H, Pourmarzi D. The effect of zinc supplementation on pregnancy outcome: a randomized controlled trial. J Matern Fetal Neonatal Med. 2016; 29: 21942198.

[22] Rumiris D, Purwosunu Y, Wibowo N, et al. Lower rate of preeclampsia after antioxidant supplementation in pregnant women with low antioxidant status. Hypertens Pregnancy 2006; 25: 241-253.

[23] Kumasawa K, Ikawa M, Kidoya H, et al. Pravastatin induces placental growth factor (PGF) and ameliorates preeclampsia in a mouse model. Proc Natl Acad Sci USA 2011; 108: 1451-1455.

[24] Ota H, Eto M, Kano MR, et al. Induction of endothelial nitric oxide synthase, SIRT1, and catalase by statins inhibits endothelial senescence through the Akt pathway. Arterioscler Thromb Vasc Biol. 2010; 30: 2205-2211.

[25] Kim YJ, Park HS, Lee HY, et al. Reduced L-arginine level and decreased placental eNOS activity in preeclampsia. Placenta 2006; 27: 438-444.

[26] Aouache R, Biquard L, Vaiman D, at al. Oxidative stress in preeclampsia and placental diseases. Int J Mol Sci. 2018; 19: 1496

[27] Ahmed A, Rezai H, Broadway-Stringer S. Evidence-based revised view of the pathophysiology of preeclampsia. Adv Exp Med Biol. 2017; 956: 355-374.

[28] Alasztics B, Kukor Z, Pánczél Z, et al. The pathophysiology of preeclampsia in view of the two-stage model. [A praeeclampsia kórélettana a kétlépcsős modell tükrében.] Orv Hetil. 2012; 153: 1167-1176. [Hungarian]

[29] Osol G, Ko NL, Mandalà M. Plasticity of the maternal vasculature during pregnancy. Annu Rev Physiol. 2019; 81: 89-111. 
[30] Valent S, Németh J, Sára L, et al. High early uterine vascular resistance values increase the risk of adverse pregnancy outcome independently from placental VEGF and VEGFRl reactivities. Eur J Obstet Gynecol Reprod Biol. 2011; 156: 165-170.

[31] Taguchi N, Rubin ET, Hosokawa A, et al. Prenatal exposure to HMG-CoA reductase inhibitors: effects on fetal and neonatal outcomes. Reprod Toxicol. 2008; 26: 175-177.

[32] Winterfeld U, Allignol A, Panchaud A, et al. Pregnancy outcome following maternal exposure to statins: a multicentre prospective study. BJOG 2013; 120: 463-471.

[33] Putra RA, Effendi JS, Permadi W, et al. Role of statin as inducer of Hmox-1 system in treatment of preeclampsia. Cell Mol Biol (Noisy-le-grand). 2018; 64: 1-4.
[34] Chimini JS, Possomato-Vieira JS, da Silva ML, et al. Placental nitric oxide formation and endothelium-dependent vasodilation underlie pravastatin effects against angiogenic imbalance, hypertension in pregnancy and intrauterine growth restriction. Basic Clin Pharmacol Toxicol. 2019; 124: 385-393.

[35] Redecha P, van Rooijen N, Torry D, et al. Pravastatin prevents miscarriages in mice: role of tissue factor in placental and fetal injury. Blood 2009; 113: 4101-4109.

(Kukor Zoltán dr., Budapest, Pf. 2, 1428 e-mail: kukor.zoltan@med.semmelweis-univ.hu)

A Semmelweis Egyetem Általános Orvostudományi Kara örömmel tesz eleget annak a hagyománynak, hogy volt diákjait jubileumi díszoklevéllel tünteti ki.

Kérjük ezért azokat az orvosokat, akik diplomájukat az egyetem jogelődjénél, a BUDAPESTI KIRÁLYI MAGYAR PÁZMÁNY PÉTER TUDOMÁNYEGYETEMEN, a PÁZMÁNY PÉTER TUDOMÁNYEGYETEMEN, a BUDAPESTI ORVOSTUDOMÁNYI EGYETEMEN, IlletVe a SEMMELWEIS ORVOSTUDOMÁNYI EGYETEMEN

$$
\begin{aligned}
& 1945 \text {-ben } \\
& 1950 \text {-ben } \\
& 1955 \text {-ben } \\
& 1960 \text {-ben } \\
& 1970 \text {-ben }
\end{aligned}
$$

szerezték meg, és szakterületükön legalább 30 évig dolgoztak, nyújtsák be kérelmüket a platina, rubin, vas, gyémánt, illetve arany díszoklevél elnyerése érdekében 2020. április 30-ig, a következő címre, az alábbi jelentkezési lapon.

\section{Semmelweis Egyetem Általános - Orvostudományi Kar \\ Dékáni Hivatal \\ 1085 Budapest, Üllői út 26. vagy 1428 Budapest Pf. 2}

A jubileumi díszoklevelek átadására elöreláthatóan októberben kerül sor. A pontos időpontról meghívó útján küldünk értesítést.

\section{JELENTKEZÉSI LAP}

\section{arany, gyémánt, vas, rubin és platina díszoklevélhez}

NÉV

(névváltoztatás feltüntetésével)

Születési idő:

Diploma kelte:

Lakcím:

Telefonszám:

E-mail cím:

Utolsó munkahely:

Rövid szakmai önéletrajz:

Aláírásommal hozzájárulok ahhoz, hogy fenti adataimat - az ALUMNI tevékenységgel összefüggésben - a SEMMELWEIS ALUMNI Iroda kezelje.

Dátum:

\section{kérelmező aláirása}

Aláírásommal hozzájárulok ahhoz, hogy a lakóhelyem szerinti illetékes önkormányzat megkeresésére, kerületi ünnepségre történő meghívás céljából az elérhetőségeim kiadásra kerüljenek.

A megfelelő válasz aláhúzandó. $\quad$ IGEN NEM

A cikk a Creative Commons Attribution 4.0 International License (https://creativecommons.org/licenses/by/4.0/) feltételei szerint publikált Open Access közlemény melynek szellemében a cikk bármilyen médiumban szabadon felhasználható, megosztható és újraközölhetö, feltéve, hogy az eredeti szerző és a közlés helye, illetve a CC License linkje és az esetlegesen végrehajtott módositások feltüntetésre kerülnek. (SID_1) 